\title{
電子線接着PETラミネート鋼板の接着性に及ぼす フェノール系オリゴマーの効果
}

\author{
増原 憲一*・森 浩治*・舆石 謙二*・佐々木 隆*2
}

Effect of Phenolic Oligomer on Adhesion of Poly (ethylene terephthalate) Film Laminated Steel Sheets by Electron Beam Curing Method

Kenichi Masuhara, Koji Mori, Kenji Koshishi and Takashi Sasaki

Synopsis : Adhesion of poly (ethylene terephalate) film by Electron Beam Curing (EBC) method which can be thought as an energy -saving process was studied for the purpose of bestowing economically design and distinctness of image on thermosetting high molecular weight polyester precoated steel sheets.

Adhesion of $\mathrm{EB}$ curable resins onto metal is generally poor. In this report, addition of $\mathrm{EB}$ curable phenolic resole oligomer with bifunctional acrylates to the top coat used for precoated steel was studied in order to increase the adhesion of an EB curable adhesive, and it was found that the phenolic oligomer is tremendously effective for the improvement of adhesion.

The reasons why the phenolic oligomer provides excellent adhesion were 1) elongation at break of the top coat to which the phenolic oligomer is added is little decreased by EB irradiation, and the formability does not reduce. 2) As the phenolic oligomer is unevenly distributed to the surface layer of the top coat, it is suggested that the contact frequency of the phenolic oligomer to the EB curable adhesive is so high that graft polymerization between them is liable to occur.

Key words : electron beam curing ; poly (ethylene terephthalate) film laminated steel sheets; ESR.

\section{1. 緒言}

近年，家電製品や内装建材において高意匠，高機能を有 する塗覆装鋼板のニーズが高まっている。柄模様を鋼板表 面に再現する意匠鋼板の製造方法としては，鋼板上にグラ ビアロールなどにより值接印刷する方法と印刷を施した塩 ビフィルムやポリエチレンテレフタレートフィルム (PETフ イルムと呼ぶ)を鋼板に積層(ラミネート)する方法などが実 用化されている1。

現在, 市販されている盐ビやPETラミネート鋼板は精密 かつ多様な柄模様の要求に対して, 外観や製造性といった 点で種々の問題点がある。例えば塭ビ鋼板は塩ビフィルム が熱可塑性であるため, 加熱接着するとフィルム表面のエ ンボス模様が潰され意匠外観を損なう場合がある。また，

PETフィルムラミネート鋼板はフィルムが有する高鮮映性 を生かし冷蔵庫の丽材などに用いられているが，これらの 用途は高度な鮮映性が要求されるので, 近年はPETと塩ビ の複合フィルムを鋼板にラミネートし, 後工程で加熱ロー ルにより鏡面化するなど, 煩雑な工程を必要とする。

一方, 筆者らは電子線硬化 $(\mathrm{EBC})$ 技術の塗覆装鋼板への
適用について検討してきた2) 7)。EBC技術は常温, 短時間硬 化が可能であり，熱に弱い材料の鋼板への塗装や接着には 好適である。しかし，一般的にEBCに用いられる塗料や接 着剤は熱硬化型の塗料や接着剤に比較して接着性が劣り,

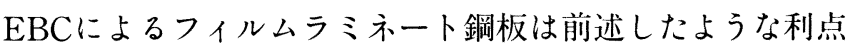
を有するが実用化された例はない。

そこで筆者らはこれらの状況に照らし, 生産性よく鮮映 性々柄模様意匠性を鋼板に付与するため, 沉用の熱硬化型 プレコート鋼板を下地とし, EBC接着剤を用いたPETフィ ルムのラミネート鋼板について検討した。EBC接着剤によ るPETフィルムとプレコート鋼板の接着性を向上させるた め種々検討した結果, フェノール系オリゴマーを接着基材 層を形成する熱硬化型上塗り塗料に添加することにより, 著しく接着性が向上することを見出した。また，接着性の 向上メカニズムについても考察したので併わせて報告する。

\section{2. 実験方法}

\section{$2 \cdot 1$ 供試材}

PETフィルムとしては厚みが $38 \mu \mathrm{m} の$ 東レ(株)製のルミラ 
Table 1. Monomer and oligomers.

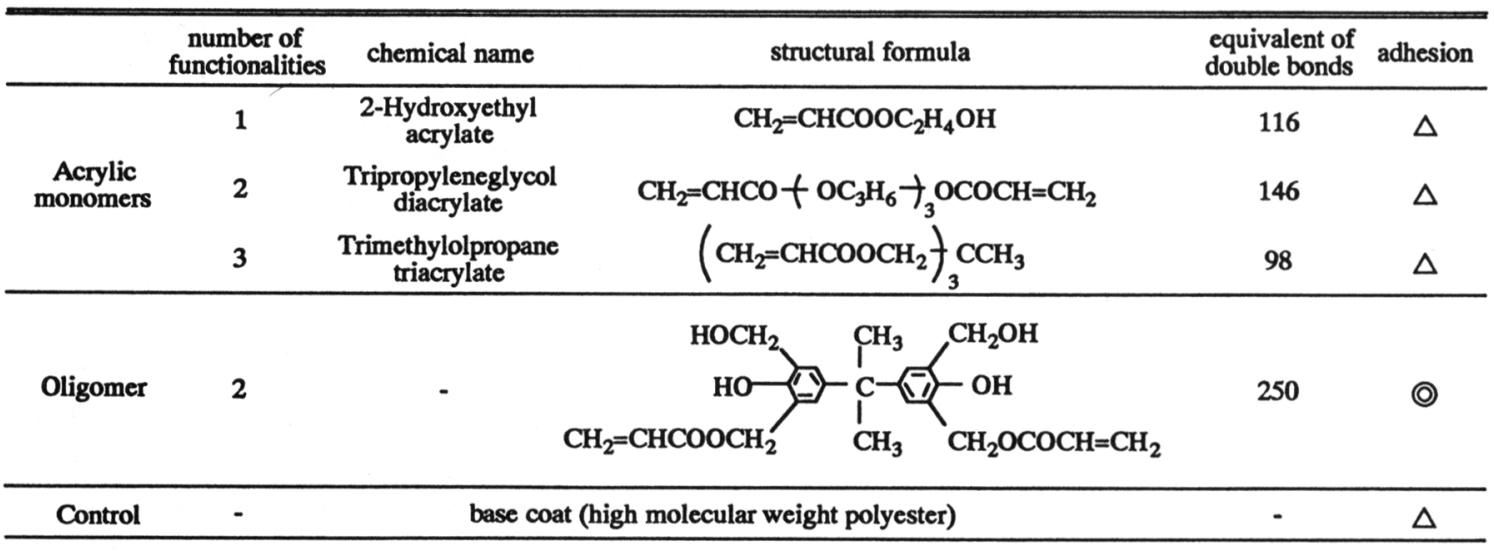

adhesion test; $8 \mathrm{~mm}$ Erichsen(\#) test $\rightarrow 800^{\circ} \mathrm{C} \times 2 \mathrm{~h}$

evalution; ():no delamination, $\bigcirc$ :below $1 \mathrm{~mm}$ delamination, $\triangle: 1-5 \mathrm{~mm}$ delamination, $\times$ :over $5 \mathrm{~mm}$ delamination

ーフィルムを用いた。 $\mathrm{EBC}$ 接着剈はフエノキシポリエチレ ングリコールアクリレート $72 \mathrm{mass} \%, 2$-アクリロイルオキ シエチルフタル酸 20 mass \%，高分子ポリエステル樹脂 8 mass\%劣配合したものを用いた。プレコート鋼板は電気 亜鉛めっき鋼板 (板厚 $0.5 \mathrm{~mm}$ ，亜鉛付着量片面 $20 \mathrm{~g} / \mathrm{m}^{2}$ ) に 塗布型クロメート処理 (全クロム付着量 $40 \mathrm{mg} / \mathrm{m}^{2}$ ) 在施し, 熱硬化型ポリエステル系プライマー塗料を乾燥塗膜厚みが $5 \mu \mathrm{m}$, 熱硬化型高分子ポリエステル系上塗り塗料(以下上 塗り塗料, 硬化した後は上塗り塗膜という)にTable 1 に示 すオリゴマー(東亜合成化学工業製, MR-XA) 塗料の不揮 発分100重量部に対し 2 20mass\%添加し乾燥塗膜厚みが $12 \mu \mathrm{m}$ なるように各々バーコーターで塗布焼き付け(到達 板温度 $230^{\circ} \mathrm{C}, 60 \mathrm{~s}$ ) し作製した。比較として用いたアクリル 系モノマーの添加量は10mass\%で一定とした。次いで, 前 記のEBC接着剤を $5 \sim 20 \mu \mathrm{m}$ 範囲でバーユーターで塗布し， PETフィルムをウェット状態で直接張り付けた後, PETフ イルムの上から電子線 $(\mathrm{EB})$ 照射した。また，上塗り塗料の 遊離塗膜は, 塗料をエチレンテトラフロロエチレンフィル 么を熱融着した電気覀鉛めっき鋼板上に同じ条件で塗布， 焼き付けした後，剝離して作製した。電子線照射は日新八 イボルテージ (株) 製エリアビーム型電子加速器により, $\mathrm{N}_{2}$ ガス雾囲気に加速電圧 $200 \mathrm{kV}$, 線量率 $250 \mathrm{kGy} / \mathrm{s}$ の照射条件 で所定線量照射した。遊離フィルムへの照射は鋼板上に塗 装した状態のままで行ない，照射後に剝離して作成した。

\section{$2 \cdot 2 \mathrm{PET}$ フィルムラミネート鋼板の接着性の評価}

PETフィルムラミネート鋼板のフィルムの接着強度は (株) 島津製作所製オートグラフAGS-100を用いて, 180度ピール 剝離試験をチャック間隔 $40 \mathrm{~mm}$, クロスヘッド速度 $0.83 \mathrm{~mm} /$ $\mathrm{S}, 20^{\circ} \mathrm{C}$ 条件で行なった。

また, PETフィルムラミネート鋼板の加工変形した部位 の接着性はFig. 1 に示すような, $5 \mathrm{~mm}$ の間隔で平行にフィ ルム表面から素地に至る切り込みと直角に同様な切り込み を入れた井型を形成させた部分をエリクセン試験機で裹面

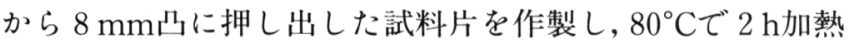

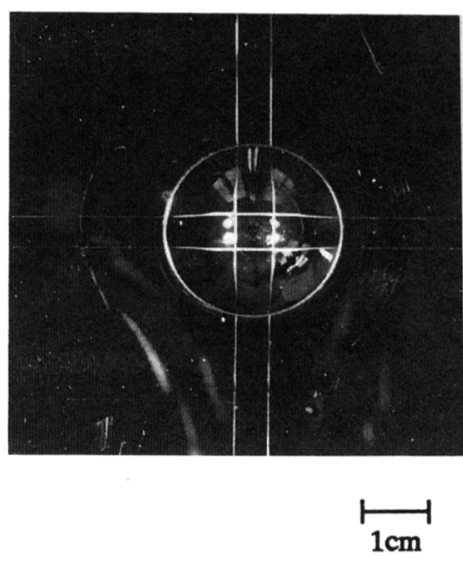

Fig. 1. 8mm Erichsen (\#) test method.

した後のフィルムの剝離状態を目視観察で評価した。

$2 \cdot 3$ 赤外線分光分析およびゲル分率の測定

加熱および電子線照射によるモノマー，オリゴマーの反 応性はフーリエ変換型赤外分光光度計 (日本電子 (株) 製FT -IR8300)を用いて赤外吸収スペクトルを測定した。また， ゲル分率は加熱, 電子線照射後の各々の塗膜をジエチルエ ーテルで 3 hソックスレー抽出し, 抽出前後の重量変化量か ら反応率を求めた。

\section{$2 \cdot 4$ 機械的性質の測定}

上塗り塗膜の機械的性質は2・1の方法で作製した遊離つ イルムを $10 \mathrm{~mm} \times 70 \mathrm{~mm}$ の寸法に切り取り, (株)島津製作所 製オートグラフ AGS-100を用いて,チャック間隔40mm, ク ロスヘッド速度 $0.83 \mathrm{~mm} / \mathrm{s}, 20^{\circ} \mathrm{C}$ 条件で引張り試験により 測定した。

\section{2・5 XPSによる表面状態の評価}

上塗り塗膜表面の官能基の状態を調べるため, PHI (株)製

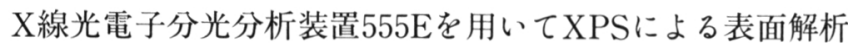
を行なった。

\section{$2 \cdot 6$ 電子スピン共鳴スペクトルの測定}

上塗り塗膜表面のラジカルの発生状態を電子スピン共鳴 (Electron Spin Resonance: ESR)により測定した。すな 


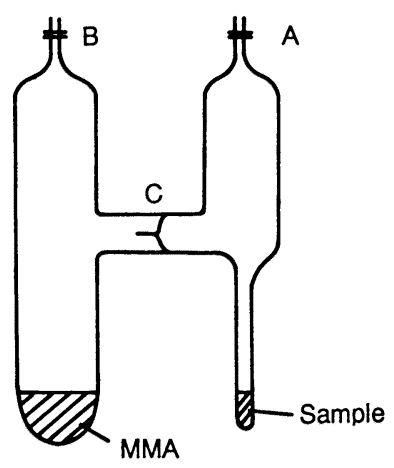

Fig. 2. H type glass tube.

わち, Fig. 2 にホす中央部Cを封じた H型管のA側底部に測 定する試料を約 $100 \mathrm{mg}$ 入れ $\mathrm{N}_{2}$ ガスで置換, $10^{-2} \mathrm{mmHg}$ の真 空に引いた。この操作を 3 问繰り这した後封印し，2・1の 条件でEB照射して直ちに液体 $\mathrm{N}_{2}$ 温度まで冷却した後, $77 \mathrm{~K}$ でESRスペクトルを測定した。次に, 室温に戻しメチルメ タクリレート (MMA) をB側底部に入れ，B側についても同 じ操作を 3 问繰り返し後封印し，15min放置した。その後中 央部のC部を破壊し, B側からA側へMMAを流入させた後, 再度室温でESRスペクトルを测定した。なお，ESRスペク トルはESR測定装置(日本電子製ESR 測定装置JES-FE

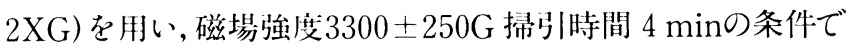
測定した。また,MMAは試薬一級のものをそのまま用いた。

\section{3. 実験結果および考察}

\section{3・1 PETフィルムの接着性に及ぼすオリゴマーおよびモノ マーの影響}

$\mathrm{EBC}$ 接着剤による熱硬化型高分子ポリエステル系プレコ 一ト鋼板へのPETフィルムの初期接着性を把握するため, 180度ピール虽離試験を行なった。その結果をFig. 3 に示す

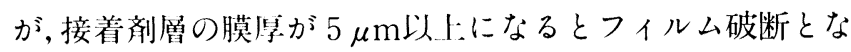
り平坦部では十分な接着性を有することがわかる。しかし， 実際の鎙板は曲げや張出し加：されて使用されるため，模 擬試馻としてエリクセン試験により加工歪みを加え，さら

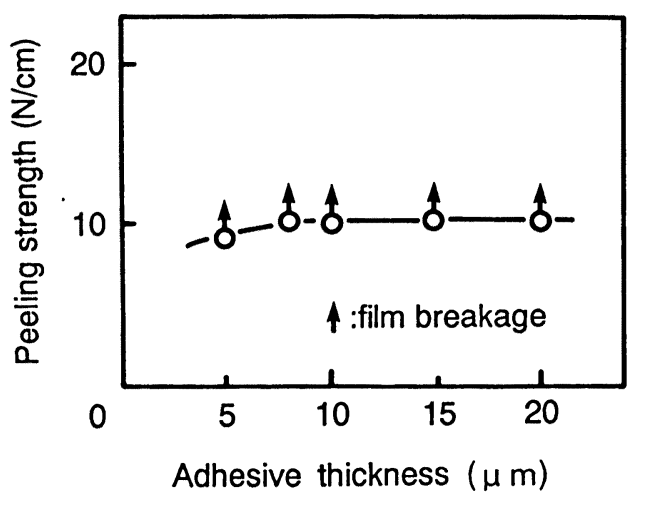

Fig. 3. Relationship between adhesive thickness and peeling strength.
にフィルムの接着性の経時変化を調べるため加熱により促 進した。いずれの試料も, 凸部井型部のフィルム切り込み 部からPETフィルムが剝離した。これはEBC接着剤の硬化 反応に伴い，接着剤樹脂が収縮し，しかも常温硬化である ため, 熱による応力緩和がほとんぞない。そのため, EB硬 化後の接着基材層である上塗り塗膜近傍に大きな内部応力 が残存するのではないかと推測される。

そこで, 接着基材層を形成する熱硬化型上塗り塗料にEB 反応性の不飽和二重結合を有するモノマーやオリゴマーを 添加し, 上に塗布されるEBC接着剤との間でグラフト重合 させることにより, 接着基材層と $\mathrm{EBC}$ 接着剤との接着力の 向上について検討した。供したオリゴマーはTable 1 に示す アクリロイル基を持つ 2 官能性のレゾール型フェノール(以 下フェノール系オリゴマーと(う)である。このフェノール 系オリゴマーの添加を試みた理由は, 接着基材層と $\mathrm{EBC}$ 接 着剂との間でグラフト重合を効率的に生じさせるには, 接 着基材層に生成したラジカルが，すぐに失活するのではな く寿命の長い(安定な)ことが必要である。一方, 遊離基捕 獲剤と呼ばれる化合物, 例えばジフェニルピクリルヒドラ ジル8)は活性化状態で安定なラジカルを生成する。これは化 学構造内にベンゼン環を有し, ベンゼン環が共鳴構造を取 り安定化するため, 隣接するラジカルは比較的安定なラジ カルとして存在するといわれている。このような観点から， $\mathrm{EB}$ 反応性のフェノール系オリゴマーに着目した。比較のた め, アクリロイル基を持つ $1 \sim 3$ 官能のアクリル系モノマ 一についても同様に調べた。接着性試験結果をTable 1 に示 寸。まず，比較として用いたEB反応性モノマーである 1 官 能性の 2 -ヒドロキシエチルアクリレート (HEA), 2 官能性 のトリプロピレングリコールジアクリレート (TPGDA), 3 官能性のトリメチロールプロパントリアクリレート (TMPTA) を添加したいずれの試料の接着性も，未添加 (上塗り塗料) 試料の接着性と同程度であった。一方, フェノール系オリ ゴマーを上塗り塗料に添加した場合は, エリクセン加工部 でのPETフィルムの接着性は著しく向上し, 剝離は全く生 じなかった。このフェノール系オリゴマーの接着性向上に

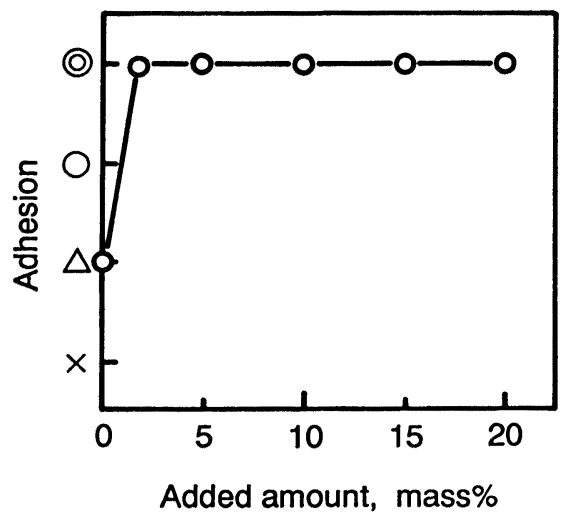

Fig. 4. Relationship between added amount of MR$\mathrm{XA}$ and adhesion. 
及ぼす添加量の影響について調べたのがFig. 4 であり，フェ ノール系オリゴマーの添加量が 2 mass\%以上でフィルムの 剝離はなく良好な接着性が得られることがわかった。以下 に接着性が向上した理由について，接着基材層である上塗 $り$ 塗膜の機械的性質，化学的性質の变化なぼの観点から検 討した。

\section{3・2 EB照射による上塗り塗膜の機械的性質の変化}

加工部での接着性は接着基材層である上塗り塗膜の変形 能と接着剤との化学的結合性に支配されると考えられる。 そこで，接着基材層を形成する上塗り塗料にオリゴマー, モノマーを添加した場合, 加熱あるいはEB照射過程で塗膜 の機械的性質がどのように変化するかを遊離塗膜の引張り 試験により調べた。結果をTable 2 に示すが，上塗り塗料に アクリル系モノマーを添加した塗膜の破断伸び，破断応力 は, 加熱過程 (熱硬化過程)で元の上塗り塗膜 (Control) の破 断伸び，破断応力に比較していずれも低下する。この理由 はモノマーと樹脂の溶解度パラメーター $(\delta)$ が異なり相溶性 があまり良くないため，加熱によりマトリックス樹脂であ る, 熱硬化型高分子ポリエステル系塗料中で自己重合し, 塗膜の架橋構造の形成を阻害したものと考えられる。さら に, EB照射により 1 官能のHEAを添加した場合を除いて, 塗膜の破断伸びは低下する。上塗り塗膜である高分子ポり エステルにEB照射されると, 分子鎖の一部にラジカルが生 じ，分子鎖同士が一部架橋反応寸ると同時に，加熱時に残 存した未反応モノマーが架橋点となり分子鎖の架橋反応が 進行する。そのため, 塗膜が剛直になるためである。

一方，良好な接着性を示すフェノール系オリゴマーを添 加した場合は，加熱による塗膜の破断伸びおよび破断応力 はモノマー添加の場合と同様に低下寸るが, EB照射による 塗膜の破断伸び，破断応力の変化は小さい。また，添加量 を増加させると破断伸びは低下するが, EB照射による変化 は小さい。その結果, EB照射による加工性の変化は小さい。

Table 2. Mechanical properties of specimens.

\begin{tabular}{|c|c|c|c|c|}
\hline \multirow[b]{2}{*}{ Samples } & \multicolumn{2}{|c|}{ elongation at break $(\%)$} & \multicolumn{2}{|c|}{ ultimate strength $\left(\mathrm{N} / \mathrm{mm}^{2}\right)$} \\
\hline & $\begin{array}{c}\text { before } \\
\text { irradiation }\end{array}$ & $\begin{array}{c}\text { after } \\
\text { irradiation }\end{array}$ & $\begin{array}{c}\text { before } \\
\text { irradiation }\end{array}$ & $\begin{array}{c}\text { after } \\
\text { irradiation }\end{array}$ \\
\hline HEA & 285 & 313 & 22.9 & 24.9 \\
\hline TPGDA & 340 & 258 & 27.2 & 30.3 \\
\hline TMPTA & 338 & 253 & 22.6 & 25.1 \\
\hline $\begin{array}{l}\text { MR-XA } \\
(2 \mathrm{mass} \%)\end{array}$ & 285 & 267 & 25.8 & 24.7 \\
\hline $\begin{array}{c}\text { MR-XA } \\
(5 \mathrm{mass} \%)\end{array}$ & 260 & 245 & 24.8 & 26.2 \\
\hline $\begin{array}{c}\text { MR-XA } \\
(10 \mathrm{mass} \%)\end{array}$ & 193 & 182 & 22.1 & 21.3 \\
\hline $\begin{array}{c}\text { MR-XA } \\
(15 \mathrm{mass} \%)\end{array}$ & 158 & 180 & 21.6 & 21.8 \\
\hline $\begin{array}{c}\text { MR-XA } \\
(20 \mathrm{mass} \%)\end{array}$ & 163 & 152 & 22.8 & 23.2 \\
\hline Control & 383 & 310 & 28.5 & 26.6 \\
\hline
\end{tabular}

HEA:2-hydroxyethyl acrylate

TPGDA:Tripropyleneglycol diacrylate

TMPTA:Trimethylolpropane triacrylate
$3 \cdot 3$ オリゴマー, モノマー添加による上塗り塗膜の化学 反応的性質の变化

次に接着基材層であるオリゴマーやモノマーを添加した 上塗り塗膜と $\mathrm{EBC}$ 接着䨩との化兴的な反応性について調心゙ るため, 加熱・EB照射の条々の過程での上塗り塗料の反応 率(ゲル分率) と赫外吸收スペクトルを测定した。ゲル分率 の測定結果をTable 3 に示すが, 元の熱硬化型高分子ポリエ ステル系塗料のゲル分摔は約 $90 \%$ であるのに対し，オリゴ マーやモノマーを添加した系でもほぼ同程度のゲル分率を 示す。このことはEB反応性オリゴマーやモノマーは加熱に よる上塗り塗料の硬化反応過程で，ほぼ问程度に反応した ことを意味する。またEB照射後のゲル分率值にも殆ど差は ないことから，オリゴマーやモノマーは上塗り塗料の加熱 過程でほぼ反応が完了したことがわかる。確認のため加熱 後, EB照射後のオリゴマーやモノマーに埽属するアクリロ イル基の二重結合 $(\mathrm{C}=\mathrm{C})$ の変化から反応状態を調べた。元 の上塗り塗料とオリゴマー，モノマーを添加した同塗料の

Table 3. Gel ratio.

\begin{tabular}{|c|c|c|}
\hline Samples & before irradiation $(\%)$ & after irradiation $(\%)$ \\
\hline HEA & 89.3 & 89.8 \\
\hline TPGDA & 89.4 & 90.7 \\
\hline TMPTA & 89.2 & 90.5 \\
\hline $\begin{array}{l}\text { MR-XA } \\
(2 \mathrm{mass} \%)\end{array}$ & 89.9 & 89.4 \\
\hline $\begin{array}{c}\text { MR-XA } \\
(5 \mathrm{mass} \%)\end{array}$ & 89.9 & 89.3 \\
\hline $\begin{array}{c}\text { MR-XA } \\
(10 \mathrm{mass} \%)\end{array}$ & 90.3 & 89.6 \\
\hline $\begin{array}{c}\text { MR-XA } \\
(15 \mathrm{mass} \%)\end{array}$ & 90.3 & 89.9 \\
\hline $\begin{array}{c}\text { MR-XA } \\
(20 \mathrm{mass} \%)\end{array}$ & 90.3 & 90.0 \\
\hline Control & 89.6 & 88.8 \\
\hline
\end{tabular}

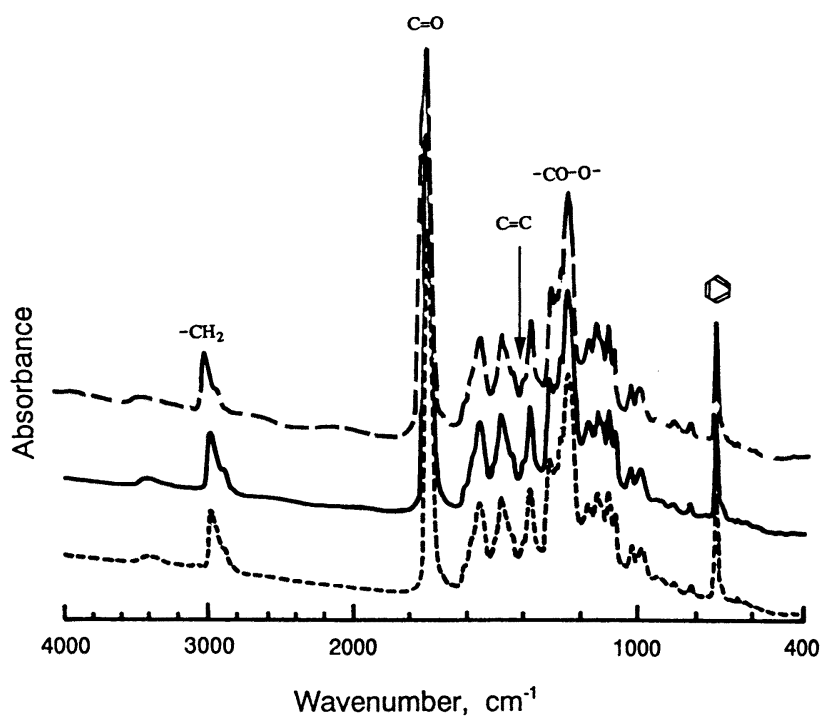

Fig. 5. Comparison of infrared spectra for films added MR-XA 20 mass\% by EB irradiation : ......; before irradiation ; after irradiation - - ; contol 
加熱硬化後の赤外吸収スペクトルを測定した結果，いずれ の試料にも $1405 \mathrm{~cm}^{-1}$ の $(\mathrm{C}=\mathrm{C})$ に基づくピークは認められな かった。Fig. 5 に一例としてフェノール系オリゴマーを20mass \%添加した系の赤外吸收スペクトルを示すが，元の上塗り 塗膜の赤外吸収スペクトルとの差は認められない。また， $\mathrm{EB}$ 照射後の赤外吸收スペクトルも, EB照射前 (加熱硬化後) のスペクトルと殁ど差がないことが確認された。

\section{$3 \cdot 4$ 接着性に及ぼす表面官能基の影響}

接着基材層である.上塗り塗膜表面の化学反応性を調べる ため, 塗膜表面の化学構造についてXPSを用いて測定した。 Fig. 6 は元の上塗り塗膜表面のXPSスペクトルを示す。本上 塗り塗料は硬化剤としてメチル化メラミンが用いられてい るが,メラミンに帯属する285.eV付近のー CN基のピークの 方が $286.3 \mathrm{eV}$ 付近のーCO基のピークより大きく, 加熱硬化 時に一部のメチル化メラミンが塗膜表面に移行濃縮してい

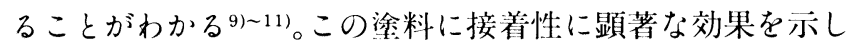
たフェノール系オリゴマーを，また比較材としてHEAを添 加した系についての同様なXPSスペクトルを測定した結果 をFig. $7 ， 8$ に亦す。両間からわかるように, Fig. 6 に比較 していずれもーCO基のピークがー $\mathrm{CN}$ 基のピークより大き いことがわかる。Table 4 は各々の試料についてーCO基の ピークのーCN基のピークに対する強度比 $(-\mathrm{CO} /-\mathrm{CN}) て ゙$ 整理したものである。元の上塗り塗膜表面の強度比は 0.86 であるのに対して, 添加した系はいずれも 1.0 以上の值を示 寸。特に接着性に顕著な効果を示したフェノール系オリゴ マーは約1.3以上:と最も大き做を亦し,フェノール系オリ ゴマーが元の上塗り塗膜表層に濃縮し易いことを示してい る。

次に, $\mathrm{EBC}$ 接着剤のオリゴマーやモノマーとのラジカル 重合反応性を確認するため，接着基材層である上塗り塗膜 表面にEBが照射された場合のラジカルの発生状態をESRで 測定した。Fig. 9 はフェノール系オリゴマー, HEAを添加 した場合についての結果である。わかりやすくするため, 元の上塗り塗膜をControlとして, 添加系のピークの大きさ

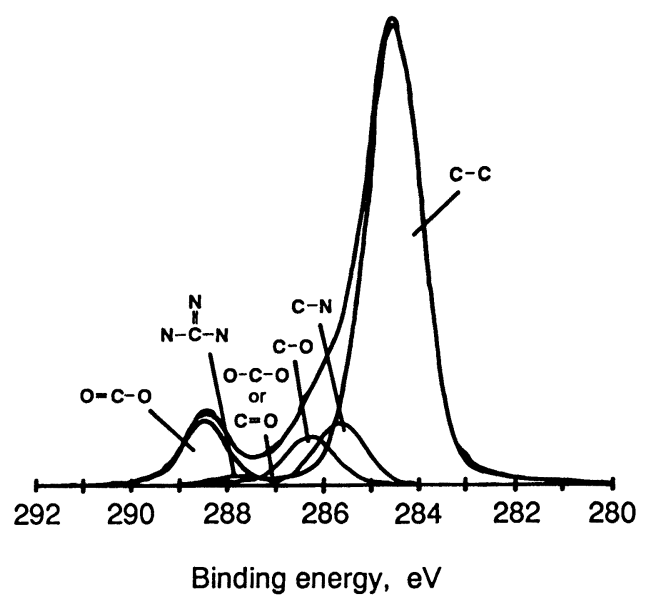

Fig. 6. XPS chart for control.

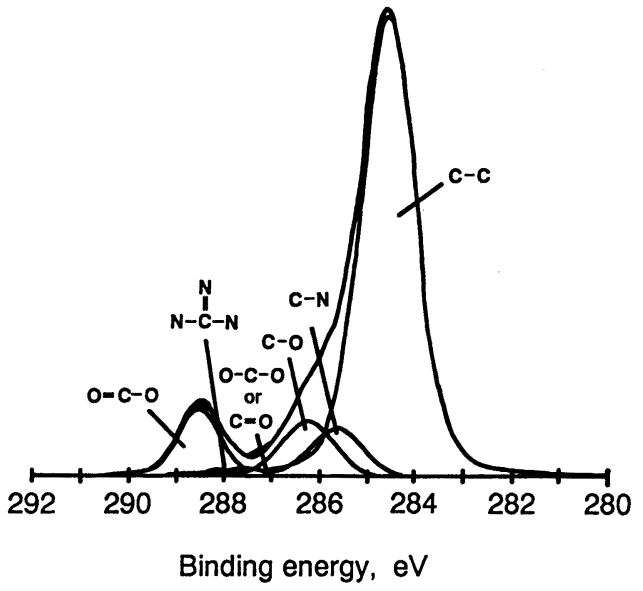

Fig. 7. XPS chart for film added MR-XA 10 mass\%.

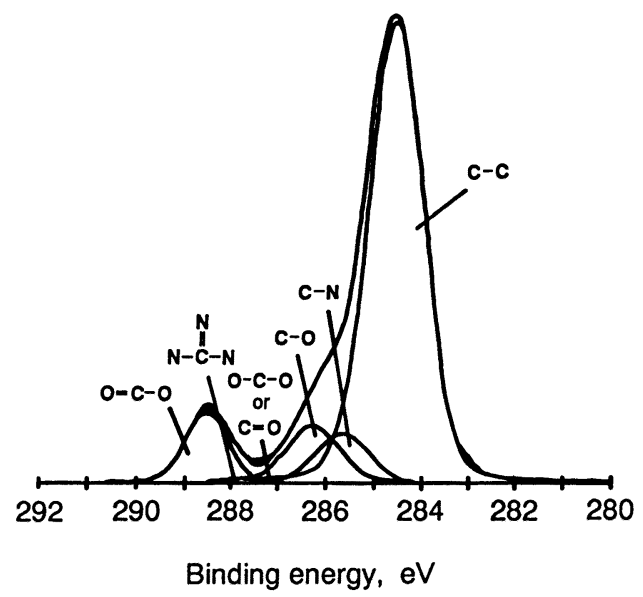

Fig. 8. XPS chart for film added HEA.

Table 4. Peak ratio of $\mathrm{C}-\mathrm{O} / \mathrm{C}-\mathrm{N}$ by ESCA analysis.

\begin{tabular}{cc}
\hline Samples & $\mathrm{C}-\mathrm{O} / \mathrm{C}-\mathrm{N}$ \\
\hline HEA & 1.22 \\
TPGDA & 1.20 \\
TMPTA & 1.21 \\
MR-XA (2mass\%) & 1.26 \\
MR-XA(10mass\%) & 1.31 \\
MR-XA(20mass\%) & 1.32 \\
Control & 0.86 \\
\hline
\end{tabular}

を相対強度比で表したものがTable 5 である。77Kにおける $\mathrm{ESR}$ スペクトルより, 元の上塗り塗膜のみでもラジカルの 発生が観測される。HEAを添加した系のESRスペクトルの 強度は元の上塗り塗膜のそれとほぼ同等程度であるが，フ エノール系オリゴマーを添加した系は 2 倍以上のESRスペ クトル強度が観察され, ラジカルの発生頻度が高いことが わかった。さらに，EBC接着凨との反応をシィミュレーシ ヨンするため, 室温で各々の試料にメチルメタクリレート (MMA) を接触させた後, ESRスペクトルを測定したところ, 上塗り塗膜のみではラジカルが失活し, 顕著なピークは観 察されなかった。しかし，フェノール系オリゴマー, HEA 


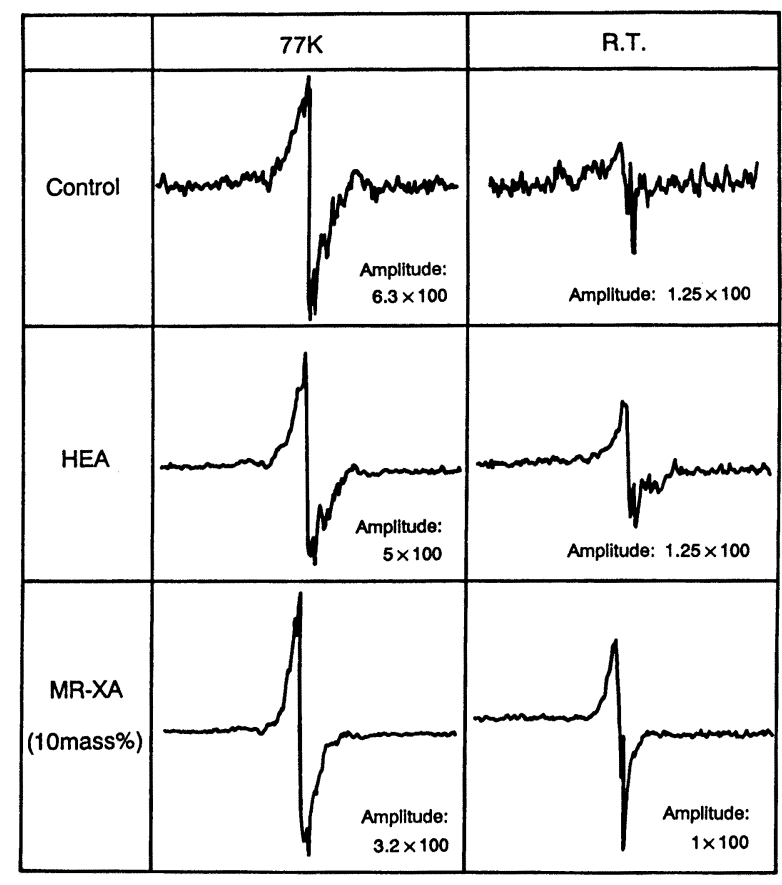

Fig. 9. ESR spectra of various samples.

Table 5. Peak ratio against control by ESR.

\begin{tabular}{ccc}
\hline \multirow{2}{*}{ Samples } & \multicolumn{2}{c}{ temperature $(\mathrm{K})$} \\
\cline { 2 - 3 } & 77 & 293 \\
\hline Control & 1 & 1 \\
HEA & 1.04 & 1.17 \\
MR-XA(10mass\%) & 2.00 & 2.80 \\
\hline
\end{tabular}

添加系では種々のラジカルが重なり, 明瞭にMMA と特定で きるピークではないが，室温においても顕著なピークが観 察され, MMAの後重合反応が起こっていることが確認され, しかもHEAよりフェノール系オリゴマーの方が 2 倍以上大 きかった。この理由は明確ではないが, 前述した『遊離基 捕獲剤』の構造から推察すると, Table 1 のフェノール系オ リゴマーの化学構造より, ベンゼン環近傍のエステル基で 生じたラジカル (遊離基)がベンゼン環の共鳴効果で比較的 安定な状態で存在できたため, MMA との後重合反応がより 顕著に生じたものと考えられる ${ }^{12)}$ 。すなわち,フェノール系 オリゴマーのベンゼン環近傍のエステル基 (-CO基) は接着 基材層である上塗り塗膜表層に濃縮しやすく, EB照射によ りベンゼン環近傍のエステル基に生じたラジカルが比較的 安定に存在し，EBC接着郕と効率的にグラフト重合反応す ることにより, 接着基材層と $\mathrm{EBC}$ 接着剤層との接着力が向 上し，残留応力に打ち勝つ接着力になったものと考えられ る。
これらのことから，EB照射による上塗り塗膜の加工性の 低下の小さいことと，接着基材層と $\mathrm{EBC}$ 接着剤層との接着 力が向上したため，加工部での接着性が问_上したと考えら れる。

\section{4. 結言}

沉用の熱硬化型高分子ポリエステル系プレコート鋼板へ のEBCによるPETフィルムの接着を検討した。課題である $\mathrm{EBC}$ 接着剤の接着性の问上には，アクリロイル基を持つ 2 官能性のレゾール型フェノール系オリゴマーを接着基材層 である上塗り塗料へ添加することが以下゙の理由で効果的で あることがわかった。

(1) フェノール系オリゴマーを含有する上塗り塗膜にEB を照射しても，塗膜の破断伸びが殆ど低下せずEB照射によ る塗膜の加工性の低下が少ない。

（2）（1）飞同様の塗膜表層のXPSを测定した結果, EB反 応性のアクリロイル基に帰属する一CO基の表面濃度が最も 高く, $\mathrm{EBC}$ 接着剤との接触頻度が高い。

( 3 ) ( 1 ) 飞同様の上塗り塗膜表面にMMAを接触させて, EB照射した場合の後重合性について調べた結果, ESRの測 定よりラジカルの発生頻度が高い。このことから，上塗り 塗膜にEBC接着剤を塗布してEB照射した場合にもグラフト 重合が起こりやすいことが推祭される。

\section{文献}

1）神田勝美, 南木 孝, 滕本準一, 野田信跒：金属表洎技術, 37 (1986), p.56

2 ) T.Tomosue, K.Mori, H.Yamabe, K.Koshiishi and K.Masuhara: 29th Mechanical Working and Steel Processing Conference, (1987), p.393

3 ) K.Masuhara, K.Koshiishi, T.Tomosue, K.Mori and N Honma : Proceeding of Conference on Radiation Curing Asia, (1988), p.231

4 ) K.Mori, K.Masuhara, T.Sasaki and I.Ishigaki : Radiation Phys. Chem., 33 (1989), p.451

5 ）森 浩治, 興不謙二, 增原憲一：茼分子論文集, 46 (1989), p.515

6 ) K.Koshiishi, T.Tomosue, K.Mori, N.Honma, E.Sukeda and K.Masuhara: Rad. Tech. 90, North America, (1990), p.478

7 ）森 浩治，舆不謙二，增原憲一：鉄々䤱， 77 (1991)，p.237

8 ）第 2 版化学大辞典 9 (化学大辞典編集委員会編)，(1966), p.367

9 ）壱岐島健问, 薄木智恣, 須滕妙子, 八内昭博, 塩沺敏明：色材協 会誌, 64 (1991), p.780

10）重国智文，大岸英夫，成濑義弘，大利康二：材料とプロセス， 6 (1993), p.1490

11）金井 洋，阙 裏二, 浜田 健, 布泪雅裕：材料とプロセス，6 (1993), p.1494

12）辰已正和，松永隆延，揖斐秀炎，川本清香：川本化学:会誌，(1992) p. 83 